\title{
Using Lyrics Lines To Strengthen Reading Comprehension
}

\author{
Edy Suseno \\ edysuseno4@gmail.com \\ IKIP Widya Darma Surabaya-Indonesia
}

\begin{abstract}
The way to persuade students to read texts is sometimes frustrating. They are reluctant to explore a lot of knowledge by reading some books or articles. This kind of condition is not good for the students to increase their perspective of knowledge. Experiencing such a thing, the teachers feel dismayed whenever see the result of their students' reading test is low. Many teachers try many methods to adapt in order to invite their students to get involved in reading practice. It is very important to find out a proper way to imply a method to enhance the students reading the material accordingly. Nevertheless, songs are parts of life all around the world people love to listen. Meanwhile, most of the students are fond of singing or listening to the songs. They copy the singers' utterances by reading lyrics to express their intention to others. Moreover, learning lyrics means to read the extensive reading. So that by posing lyrics often to discuss with makes students be accustomed to comprehending the content of the various texts. Step by step they start loving reading. Finally, their competence to grab the message of the texts is enhanced.
\end{abstract}

Keywords: Automatomacy, Receptive, Productive, Notice, Competence

\section{INTRODUCTION}

Reading is the most effective way to get information people to need. But not all people want to read some materials to satisfy their curiosity. They are more likely to be reluctant to read pages of papers. Their need to absorb a lot of information is inevitable to see the development of anything in the world instead.

Some strategies are implied to gain the learners' interest to read. Some educators provide short stories with marvelous topics and titles. Short stories are sometimes effective to invite learners to read a lot. Short stories are short and the readers can grab the holistic stories in a short time. Nevertheless, many students became passive when they faced a reading text. They seem reluctant to read the material. Another way to persuade students to get involved is by motivating them with various strategy. In teaching reading, the teachers are usually inviting the students to read the same material. It is provoking boredom (Sasson, 2007). 
Moreover, talking about short story teachers can use lyrics to be a tool to discuss with. It sounds interesting because learners can sing the song while reading the lyrics as well. Learners will learn both pronunciation and reading. Like Anvari et al. 2002 in examined relationships among pronunciation, reading, and comprehension in 100 preschoolers. He said that using music for classroom need is very beneficial. Listening music means learning reading, listening, and speaking. The listeners will learn what the lyrics talk about, how to pronounce the words and phrases, and how to grab the message. The students of IKIP Widya Darma Surabaya used this kind of method in the classroom setting to see the effectiveness of using music to enhance their skill in reading comprehension.

\section{Background}

Many students have withdrawn themselves from reading activity. It is triggered by the activity itself. It is sometimes presented in an undesired way. Students tend to get involved in the way they love to do. On the other hand, choosing a proper method to invite students to read a lot is challenging. Reading is a window to see the beauty of knowledge. Most students love to sing or listen to songs. Inviting them to discuss the content of lyrics seems wonderful. It enables them to get involved in teaching learning process because lyrics are part of the song. They unify and complete to each other (Orlova, 2003)

Indeed, songs are part of life. And they are as a tool to learn the language. Gugliemino (1986) in Schoepp 2001 stated that the activity of singing happens in any occasions. It could happen in the car, in the room, in the outdoors, and so forth. Teachers and students could use music in a classroom setting. It will benefit them to enhance the lesson.

\section{Lyrics Of The Songs}

Lyric is a script of a song. It contains all the words the singer sings. It has paragraphs that listeners use to follow what the singer says. Reading lyrics could enhance the ability of learners to understand the message of the song. Meanwhile, by reading a lyrics while singing, listeners can get involved emotionally. They can infer the message of lyrics deeply by listening to the way the singer utters the words. The color of the singers' tones could lead the listener to imagine the situation inferred. It triggers students to be autonomous learners. Choosing music as a tool to enhance the students' involvement in teaching learning process could benefit both students and teachers. Students will be triggered a lot by giving them the opportunity to expose the song they love to listen or sing. It means that students will learn English more than ever. Schoepp (2001) said that using music to enhance the lesson is helpful. The students could find their desired ones to listen after school. If it happened quite often, it could better the students' competence in the lesson.

\section{Grammar in Lyrics}

Grammar is a rule used by learners to construct sentences. By implementing grammar rule, learners will get a clue to convey their intention accordingly. Applying grammar rule correctly will ease both parties to understand to one 
another. The sentences include in lyrics also contains the form of grammar. Learners could see how the pattern of grammar works in constructing sentences in lyrics.

Moreover, by reading the content of lyrics, learners can analyze what tenses used. They will learn how the sentences constructed. This kind of learning will help learners recall the grammar rule they had learned and the way it works in a natural setting. Y00 (2002) stated that filling the gap on the listening quiz is challenging for teaching grammar. The teacher could delete the words concerning grammar on the lyrics. This kind of activity could trigger the students to learn how the grammar work. It is also lead the students to grab the message of the lyrics.

\section{Phonological Knowledge}

Learning speaking is conducting the way each word pronounced. Learning pronunciation is important. People will misunderstand among them if they pronounce the words incorrectly. There are many ways to learn pronunciation. One of them is by using music.

Meanwhile, in a song learners can listen to the words pronounced in a slow pace. They will learn how the words pronounced. Some words are pronounced blended like give up, hurry up, and so on. They will help learners to adapt to the natural setting. In natural conversation, people tend to speak fast and blend some words. By learning English through lyrics will assist learners to learn the accurate enunciation and the way to use the appropriate words in speaking. Yoo (2002) said that the singer pronounces the word in normal speed. This kind of thing is very important for students to learn. In speaking practice, the speaker speaks at normal speed. By listening to music a lot, the students will be accustomed to hearing the normal speed conversation.

\section{Colloquial In Lyrics}

Colloquial is also called slang. It is an informal expression used in the written and spoken setting. It is used among native speakers to convey their intention. It is something difficult to understand by ESL students. They need to learn it from any media provided native speakers' utterance.

Some songs are excellent examples of colloquial English, that is, the language of informal conversation. The song entitles "My Best Was Never Good Enough" by Bruce Springsteen contains colloquial language use. The phrases like "Every cloud has a silver lining." and "Every dog has his day." are the two things that could not be translated word for word. Therefore, exposing music to the students as many as they want is harvesting fruits (Orlova, 2003).

Moreover, Schoepp (2001) said that students could use music to learn informal expression. There is a lot of expressions that the students can learn. In this case, reading lyrics quite often could establish colloquial building. Learners will know more about informal English.

\section{Problem-Solving}


The lines in each paragraph are quite meaningful. It seems to compress a long story or situation to be short and imaginative. It represents the condition that the composer wants to share to listeners through the song. It is a kind of model learners could copy in responding stimulus in daily life. Learners will see how other people defend themselves to escape from difficulties.

The message of the song often happens to other people. The listeners who ever experienced such condition tend to enjoy each line of the lyrics. Upendran (2001) said that the teacher could ask the students to collect their favorite lyrics and songs. The teacher could use those kinds of material for different purposes. Both the teachers and students could enjoy the lesson taken from the material the students love.

\section{Automatization}

Automatization is a process experienced by learners repeating to learn components of language over and over. The level of success in learning language by using Automatization varies. It depends on the frequency of learning implied by learners. Moreover, using songs to learn English could be Automatization. Learners will listen to them as many as they want to. It enables learners to replay the sound of music desirable.

On the other hand, Gatbonton and Segalowitz (1988, p.473) in Schoepp 2001 define automaticity as the process of developing the ability to express the idea and producing fluent utterance. Using songs can help automatize the language development process.

\section{Extensive Reading}

Extensive reading is reading a lot. It is also reading for pleasure. It is a kind of way to boost the learners' level of background knowledge to comprehend any kind of reading materials. On the other hand, by developing it inside or outside the classroom, students will develop their vocabulary building. They can choose any kind of topic they love to.

Moreover, to meet the enjoyment of reading, the teacher should provide the material that fit with the students' favorite. The obstacle of unfamiliar words or phrases means disturbance. The comfortable reading is getting a failure to reach. It could be said that the goal of the extensive reading is fluency and enjoyment in the reading process (Clarity, 2007).

Reading lyrics could establish extensive reading activity. There are a lot of songs with a various level of difficulty. Learners could choose the desired one to satisfy their need without be abrupted by vocabulary.

\section{Noticing}

Noticing is focusing on the meaning of sentences and the form of structure used to convey the intention of the writer in the input. It is more than reading. The readers tend to see deeply how the sentences constructed and the message of the passage delivered. This kind of activity will assist learners to keep grammar rule to stay longer in their head and to lead them to comprehend the message of the passage. 
Moreover, Noticing is basically the way how to comprehend the structure and the meaning of the input to build the internalization of grammar rule (Batstone, 1996 in Noonan, 2003).

On the other hand, lyrics could be used as a tool to notice. Learners could see what grammar rule implied in each sentence and what message the composer intended.

\section{Analyzing Lyrics Lines}

Analyzing is an activity to dig deeper into the paragraph read. Learners could synthesize any angel of perspectives to analyze the content of the paragraph. Meanwhile, reading lyrics is an activity to read an extensive reading as well. The lines in lyrics consist of some structures, vocabulary, and various expression that enable them to analyze.

Lyrics contains formal and informal language. It includes the implication of grammar rule, idiomatic, colloquial, and cultural content. Learning lyrics is also learning the fundamental of language. It also can be figured out as exposing the students to the critical-thinking (Ahola, 2005)

Briefly, using lyrics as a tool to analyze the content of the paragraph could enhance learners' reading comprehension ability.

\section{Receptive Vocabulary}

While people are listening and reading, they listen and read some words. They try to understand the words based on the dictionary they learn. It seems that the meaning infers is lexical. It depends on the definition of the words from the vocabulary. When learners get difficult to understand a word or phrase, they try to skip it or search it in the dictionary. The most important thing for them is grabbing the message they hear or read.

Nation (2001) in Cervatiuc (2008) said "A widely accepted distinction related to vocabulary knowledge refers to lexical "receptive knowledge", which involves the ability to understand a word while listening or reading."

\section{Productive Vocabulary}

In speaking and writing people tend to use words concisely. In speaking for an instant, people need to pronoun and choose words properly to accommodate understandable conversation. The two parties can exchange their response to grab the intention. Furthermore, people need to write and choose words properly to gain desirable intention. They cannot ignore the spelling of the words.

Thus, Nation (2001) in Cervatiuc (2008) said that students learn vocabulary to use in speaking and writing. The ability to use the supply of vocabulary in both speaking and writing is called "productive knowledge".

\section{Vocabulary And Lyrics Lines}

Vocabulary is a list of words needed to construct sentences. With vocabulary, speakers could express their intention. On the other side, by reading the lines in lyrics, readers also learn some new words. Any kind of methods they use to 
interpret the meaning of the words. They will establish the vocabulary building. Students can use a dictionary, google translate, or discuss it with other people who know more. Meanwhile, they are also learning colloquial.

Moreover, Brown (2006) said "Practicing lyrics reading, studying the vocabulary, and listening to various songs can help students become more familiar with the popular music and make them more confident in their ability to listen and understand the world around them." It means that by leaning lyrics learners are also building their vocabulary.

\section{Normal And Informal English In Lyrics Lines}

The content of lyrics could be formal or informal setting. It depends on the type of the song. It is very important for students to recognize formal and informal English. By knowing formal and informal English, learners would be confident in which setting they would like to use in delivering utterance.

Later on, Schoepp (2001) said that providing songs as the resource of learning is bringing students into genuine language learning. Some formal and informal speeches could be found in the lyrics. Thus, they provide learners with adequate words to comprehend passages.

\section{Discussing Lyrics Content In Groups}

To boost the learners' competence in interpreting the intention of lyrics by discussion is fun. Discussing lyrics in a group could lessen the rigidness. They will be free to express their opinion to respond to other members' ideas.

Thus, educators can use it as a tool to better their students' curiosity. Curiosity is a good asset for students to dig any information deeply. It will prevent them from lacking ideas to deliver.

By triggering their curiosity, both teachers and students can create an environment of teaching-learning process to be interesting. Although it is not the only way to invite students to get involved, it is a good way to create a good atmosphere of learning.

Indeed, using a song as the material is fruitful for both the teachers and students. Although, it is not the only way to invite the students to get involved in the discussion, at least the teaching-learning process could run accordingly (Cullen,1998).

\section{Grabbing the Messages of Lyrics Lines}

The discussion is a meaningful learning process to understand what the passage about. The parties could exchange their ideas to see the perspective from different angles.

By making discussion, students are actually to learn to grab the message of the song. Repeating activities to discuss the content of lyrics will enable students to see the beauty of the message. It can boost learners to do again and again. 
On the other side, noticing and analyzing is also contributing a great deal of support to grab the message of lyrics. The way how sentences are constructed and the meaningful content of each line are the things learners focus on.

The most important thing is learners can get fruits by doing discussion, noticing, and analyzing to better their reading comprehension competence. They are able to learn what the content of the text about. It can lead them to be autonomous. They will do that by themselves.

On the other hand, the teacher could give a task to the students to discuss the song they listen. This kind of activity could lead them to be less teacher dependent. The focus of this learning is how to understand the intention of the lyrics (Sasson, 2007).

\section{METHOD}

To collect and analyze the data, I used Rubric and the mixing of the quantitative and qualitative method. The Rubric was used to collect data in pre-test and posttest. Data sources were the competence of the participants measured by Rubric. The competence of students in vocabulary building and reading comprehension was measured by using Rubric. It was done before the treatment and after.

Comparing the scores in both pre-test and post-test was a kind of way to see the progress of the treatment. To emphasize the description of the finding, I used some charts. It would be clearer to tell what I had found. The mixing method of qualitative and quantitative was used to analyze the data of this finding to see the effectiveness of using lyrics lines to enhance the skill of reading comprehension.

To emphasize the description of comparison, the chart was used in all discussed field.

\section{ACTIVITY}

\section{Pretest}

Before joining the treatment, students did a pre-test. The material of pre-test could be found on the appendix. This kind of step is very important to see the background knowledge they belonged to. It is the point to be the one to compare with.

\section{Exposing lyrics}

Before getting the treatment started, the teacher distributed lyrics text to the students. It is used to learn what the content about is. The teacher invited the students to read line by line. It doesn't matter whether they understand it.

\section{Listening to the song}

The teacher was playing the song which could be heard by the students in the last row. It was played two times to experience listening to the proper pronunciation of the words. While listening to the song, the student was noticing the lines.

\section{Translating lyrics}


After listening to the song, the teacher invited the students to read line by line and translate them together. Each line they read and translated, the teacher asked them what the line talked about.

\section{Discussing lyrics}

After finishing all the lines to read and translate, the teacher discuss the conclusion of the lyrics. The teacher also invited students to compare their experience with the content of the lyrics.

To complete the procedure of discussion, the teacher repeating step $\mathbf{1}$ to $\mathbf{5}$ with two other songs. This kind of activity was done for one semester. There were two periods of time in a week.

\section{DISCUSSION}

The scores of pre-test and post-test could be seen on appendix.

Comparing the average scores between pre-test and post-test is very important to see the effectiveness of using lyrics to boost vocabulary building and reading comprehension.

The average score for Pre-test is 56.4. Based on the criteria that the score 56.4 is categorized bad. The difficulty of finding the right words in conveying intentions and dominated by long enough pause to say a word or two could not understand what the passage is talking about. Could not answer a single question both in written and spoken setting

On the other hand, the score 84.8 in post-Test is categorized well. There is no difficulty in choosing the right words to convey the intentions but it takes a few moments to remember the words he has learned so that there are some pauses in speaking and some incomplete answers in the written setting. Answer more than 5 questions properly both in a written and spoken setting with some incomplete answers.

It means that the progress of the students' competence in vocabulary building and reading comprehension is good. Moreover, it could be said that the use of lyrics to strengthen reading comprehension and vocabulary building is good.

The chart below illustrates the progress of the treatment 
The comparison of the average scores between pre-test and post-test

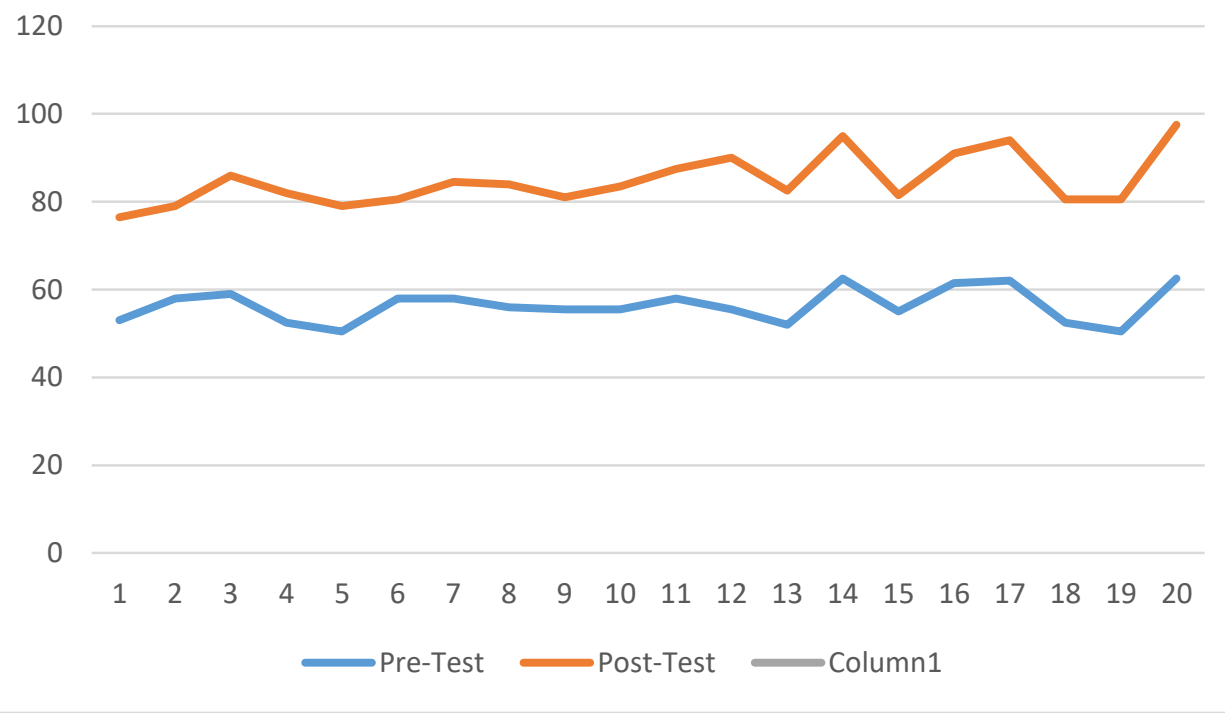

From the chart above, we could see that each participant got progress although the level of development is different from one person to the other. It could be said that using lyrics of the song to enhance reading comprehension skill is effective.

\section{CONCLUSION}

Using lyrics as a tool to teach reading in a classroom could be beneficial for both teachers and students. Lyrics include formal and informal expression used both in written and spoken English to enhance the background knowledge of the readers' vocabulary building. Teachers will facilitate the students to enhance much more ideas to invite them to be creative. Their creativity can inspire the teachers themselves to develop the method of reading comprehension to adopt in teaching reading.

Indeed, posing lyrics to students quite often can lead them to better their way to comprehend the passages in written English and the words in spoken English. Finally, their desire to read various texts is fostered and their perspective to understand the content of passages will be developed.

\section{SUGGESTIONS}

To enhance students' reading comprehension skill, the teacher should create a fun atmosphere for reading learning. Inviting students to get involved in comprehending the passage is very important. The use of the lyrics of music is an alternative material to boost the students' interest. Bit by bit their competence in grabbing the message of the text is increasing. 


\section{REFERENCES}

Ahola, S.K. 2005. Digging Deeper into Songs: A Writing Activity. The Internet TESL Journal, Vol. XI, No. 2. From http://iteslj.org/Lessons/AholaSongs.html

Brown, J.L.M.2006.Rhymes, Stories, and Songs in the ESL Classroom. The Internet TESL Journal, Vol. XII, No. 4. From: http://iteslj.org/Articles/Brown-Rhymes.html

Cervatiuc, A.2008.ESL Vocabulary Acquisition: Target and Approach. The Internet TESL Journal, Vol. XIV, No. 1. From: http://iteslj.org/Articles/Cervatiuc-VocabularyAcquisition.html

Clarity, M. 2007. An Extensive Reading Program for Your ESL Classroom. The Internet TESL Journal, Vol. XIII, No. 8. From http://iteslj.org/Techniques/Clarity-ExtensiveReading.html

Cullen, B. 1998. Music and Song in Discussion. The Internet TESL Journal, Vol. IV, No. 10. From http://iteslj.org/Techniques/Cullen-Music.html

LIM, H. And GODEFROID, A. 2013. Automatization in second language sentence processing: A partial, conceptual replication of Hulstijn, Van Gelderen, and Schoonen's2009 study. Michigan State University. From http://www.academia.edu/7186703/Automatization_in_second_language_ sentence_processing_A_partial_conceptual_replication_of_Hulstijn_Van _Gelderen_and_Schoonens_2009_study

Noonan, F.J.2004. Teaching ESL Students to "Notice" Grammar. The Internet TESL Journal, Vol. X, No. 7, from http://iteslj.org/Techniques/NoonanNoticing.html

Orlova, N.F.2003.Helping Prospective EFL Teachers Learn How to Use Songs in Teaching Conversation Classes. The Internet TESL Journal, Vol. IX, No. 3. Taken from: http://iteslj.org/Techniques/Orlova-Songs.html

Sasson, D. 2007. Six Tips for Teaching Lower Level Junior High School ESL Students. The Internet TESL Journal, Vol. XIII, No. 7. From http://iteslj.org/Techniques/Sasson-LowerLevelJHS.html

Schoepp, K. 2001. Reasons for Using Songs in the ESL/EFL Classroom. The Internet TESL Journal, Vol. VII, No. 2. From http://iteslj.org/Articles/Schoepp-Songs.html

Upendra, S. 2001. Teaching Phrasal Verbs Using Songs. The Internet TESL Journal, Vol. VII, No. 7. From http://iteslj.org/Techniques/UpendranPhrasalVerbs.html

Walton, P.D., Canaday, M. and Dixon, A. 2002. Using Songs and Movement to Teach Reading to Aboriginal Children. From http://www.cclcca.ca/pdfs/FundedResearch/Walton-FinalReport.pdf

Yoo, I.W. 2002.Focused Listening with Songs. The Internet TESL Journal, Vol. VIII, No. 7. From: http://iteslj.org/Techniques/Yoo-Songs.html 


\section{APPENDIX}

\section{Pre-test and Post-test}

\section{A. Text Questions}

\section{The common cold}

The common cold, also known simply as the cold, is a viral infectious disease of the upper respiratory tract that primarily affects the nose. It is also possible that the throat, sinuses, and voice box get also affected. It is the most frequent infectious disease in humans. The average adult gets two to four colds a year, while the average child may get six to eight. They occur more commonly during the winter. These infections have been with humanity throughout history.

\section{Signs and symptoms}

Signs and symptoms may begin less than two days following exposure. They include coughing, sore throat, runny nose, sneezing, headache, and fever. People usually recover in seven to ten days. Some symptoms may last up to three weeks. In those with other health problems, pneumonia may occasionally develop.

\section{Cause}

Well over 200 virus strains are implicated in the cause of the common cold; the rhinoviruses are the most common. They spread through the air during close contact with infected people and indirectly through contact with infected objects. Risk factors include going to daycare, not sleeping well, and psychological stress. Symptoms are mostly due to the body's immune response to the infection rather than to tissue destruction by the viruses themselves.

\section{Influenza versus the common cold}

In the early stages of infection, it can be difficult to distinguish between the common cold and influenza. The latter is commonly referred to as the flu and is usually a more severe disease than the cold. In fact, influenza is a mixture of symptoms of common cold and pneumonia. Influenza patients may suffer from fever, body aches, headache, diarrhea, sore throat, runny nose, vomiting, and fatigue.

\section{Treatment of the common cold}

There is no vaccine for the common cold. The primary methods of prevention are the following:

- hand washing; 
ELT Worldwide Vol 5 No 2 (2018)

Suseno : Using Lyrics Lines to ...

- not touching the eyes, nose or mouth with unwashed hands;

- and staying away from other sick people.

Some evidence supports the importance of using face masks.

No cure for the common cold exists, but the symptoms can be treated.

Nonsteroidal anti-inflammatory drugs (NSAIDs) such as ibuprofen may help with pain. Antibiotics should not be used. In addition, evidence from research does not support any benefit from cough medicines.

Questions

1. What can you deduce from the text above?

2. What to do if it happens to you or someone you love?

3. Tell us about the way to prevent such kind of disease comes to happen!

\section{B. Conversation Questions}

- What is good behavior? What is bad behavior?

- Were you well-behaved as a child?

- Why do some children seem naturally well-mannered, while others seem difficult?

- Were you a well-behaved child?

- How do you raise well-behaved children?

- What influences you to make good choices?

- Have you ever not tolerated someone's behavior?

- Is there any behavior that you would not find acceptable?

- What are some examples of bad behavior?

- What is the worst behavior you have seen?

\section{Assessment}

\section{Pre-test}

\begin{tabular}{|c|c|c|c|}
\hline $\begin{array}{c}\text { Id } \\
\text { number }\end{array}$ & Vocabulary & Comprehension & Average \\
\hline 1 & 56 & 50 & 53 \\
\hline 2 & 62 & 54 & 58 \\
\hline 3 & 63 & 55 & 59 \\
\hline
\end{tabular}




\begin{tabular}{|c|c|c|c|}
4 & 55 & 50 & 52.5 \\
\hline 5 & 50 & 51 & 50.5 \\
\hline 6 & 61 & 55 & 58 \\
\hline 7 & 60 & 56 & 58 \\
\hline 8 & 55 & 57 & 56 \\
\hline 9 & 56 & 55 & 55.5 \\
\hline 10 & 55 & 56 & 55.5 \\
\hline 11 & 63 & 53 & 58 \\
\hline 12 & 60 & 51 & 55.5 \\
\hline 13 & 54 & 50 & 52 \\
\hline 14 & 68 & 57 & 62.5 \\
\hline 15 & 58 & 52 & 55 \\
\hline 16 & 65 & 58 & 61.5 \\
\hline 17 & 67 & 57 & 62 \\
\hline 18 & 54 & 51 & 52.5 \\
\hline 19 & 51 & 50 & 50.5 \\
\hline 20 & 66 & 59 & 62.5 \\
\hline & & Average & 56.4 \\
\hline
\end{tabular}

\section{Post-test}

\begin{tabular}{|c|c|c|c|}
\hline $\begin{array}{c}\text { Id } \\
\text { number }\end{array}$ & Vocabulary & Comprehension & Average \\
\hline 1 & 75 & 78 & 76.5 \\
\hline 2 & 78 & 80 & 79 \\
\hline 3 & 84 & 88 & 86 \\
\hline 4 & 81 & 83 & 82 \\
\hline 5 & 78 & 80 & 79 \\
\hline 6 & 79 & 82 & 80.5 \\
\hline 7 & 83 & 86 & 84.5 \\
\hline 8 & 80 & 88 & 84 \\
\hline 9 & 78 & 84 & 81 \\
\hline 10 & 80 & 87 & 83.5 \\
\hline 11 & 85 & 90 & 87.5 \\
\hline 12 & 87 & 93 & 90 \\
\hline 13 & 79 & 86 & 82.5 \\
\hline 14 & 92 & 98 & 95 \\
\hline 15 & 78 & 85 & 81.5 \\
\hline 16 & 88 & 94 & 91 \\
\hline
\end{tabular}




\begin{tabular}{|c|c|c|c|}
17 & 92 & 96 & 94 \\
\hline 18 & 77 & 84 & 80.5 \\
\hline 19 & 78 & 83 & 80.5 \\
\hline 20 & 96 & 99 & 97.5 \\
\hline & & Average & 84.8 \\
\hline
\end{tabular}

\section{Criteria:}

$$
\begin{aligned}
& 50-59=\text { very bad } \\
& 60-69=\text { bad } \\
& 70-79=\text { fairly good } \\
& 80-89=\text { good } \\
& 90-100=\text { Excellent }
\end{aligned}
$$

\section{The description of vocabulary assessment}

\begin{tabular}{|c|l|l|}
\hline No & Rating scores & Description \\
\hline 1 & $50-59$ : very Bad & $\begin{array}{l}\text { The difficulty of finding the right words } \\
\text { in conveying intentions and dominated } \\
\text { by long enough pause to say a word or } \\
\text { two and could not understand what the } \\
\text { passage is talking about. }\end{array}$ \\
\hline 2 & 60-69: Bad & $\begin{array}{l}\text { The difficulty of finding the right words } \\
\text { in conveying intentions and dominated } \\
\text { by long pauses to say three or more } \\
\text { words in speaking and could understand } \\
\text { a little bit about what the passage is } \\
\text { talking about. }\end{array}$ \\
\hline 3 & $\begin{array}{l}\text { 70-79: Fairly } \\
\text { Good }\end{array}$ & $\begin{array}{l}\text { Not experiencing too many difficulties } \\
\text { in finding the right words to convey the } \\
\text { intentions and dominated by short } \\
\text { pauses to say three or more words and } \\
\text { any improper answers in the written } \\
\text { setting. }\end{array}$ \\
\hline \multirow{2}{*}{$\begin{array}{l}\text { There is no difficulty in choosing the } \\
\text { right words to convey the intentions but } \\
\text { it takes a few moments to remember the }\end{array}$} \\
\hline
\end{tabular}




\begin{tabular}{|c|c|l|}
\hline & & $\begin{array}{l}\text { words he has learned so that there are } \\
\text { some pauses in speaking and some } \\
\text { incomplete answers in the written } \\
\text { setting. }\end{array}$ \\
\hline 5 & $90-100:$ Excellent & $\begin{array}{l}\text { There is no difficulty in choosing the } \\
\text { right words to convey the intentions and } \\
\text { imply the proper pauses in the } \\
\text { conversation and proper answers in the } \\
\text { written setting. }\end{array}$ \\
\hline
\end{tabular}

\section{The description of reading comprehension assessment}

\begin{tabular}{|c|l|l|}
\hline No & Rating scores & Description \\
\hline 1 & 50-59: Very Bad & $\begin{array}{l}\text { Could not answer a single question both } \\
\text { in the written and spoken setting. }\end{array}$ \\
\hline 2 & $60-69:$ Bad & $\begin{array}{l}\text { Could answer less than 3 questions } \\
\text { properly in both written and spoken } \\
\text { setting. }\end{array}$ \\
\hline 3 & $\begin{array}{l}\text { G0-79: Fairly } \\
\text { Good }\end{array}$ & $\begin{array}{l}\text { Could answer less than 6 questions } \\
\text { properly in both written and spoken } \\
\text { setting. }\end{array}$ \\
\hline 4 & $80-89:$ Good & $\begin{array}{l}\text { Answer more than } 5 \text { questions properly } \\
\text { both in a written and spoken setting } \\
\text { with some incomplete answers. }\end{array}$ \\
\hline 5 & $90-100:$ Excellent & $\begin{array}{l}\text { Answer all the questions properly both } \\
\text { in the written and spoken setting. }\end{array}$ \\
\hline
\end{tabular}

